\title{
PROSVJETITELJSTVO U HRVATSKOJ KNJIŽEVNOJ HISTORIOGRAFIJI - SADRŽAJ I OPSEG POJMA
}

\section{Goranka Šutalo Davor Dukić}

UDK: 930:821.163.42“17“

Sažetak: Projekt koji je započeo kolokvijem Hrvati i Srbi u Habsburškoj Monarhiji u 18. stoljeću: interkulturni aspekti 'prosvijećene' modernizacije, a koji bi trebao imati za cilj Leksikon hrvatskog i srpskog prosvjetiteljstva, i sam je u neku ruku prosvjetiteljski. Ideja leksikona izraz je, naime, vjere u pojmove, u mogućnost njihova široko prihvatljivog određenja i usustavljivanja. Pritom leksikonska/enciklopedijska praksa uvijek nastoji prezentirati postojeće stanje spoznaje, što ponajprije podrazumijeva njezinu kritičku rekapitulaciju, dok rekonceptualizacija - promjene u definicijama ključnih pojmova, uvođenje novih koncepata, izmjene u kanonskim popisima ličnosti, tekstova, događaja i sl. - ostaje na razini začina, dobrodošlog dodatka s kojim se ne smije pretjerati. U skladu s time ovaj je prilog uvod u uvod u elaboraciju pojma prosvjetiteljstvo u hrvatskoj kroatističkoj književnoj historiografiji. Cilj, naravno, nije ograničavanje na (jedno)nacionalnu vizuru, već sustavan opis segmenta pojedinačne kulture, ${ }^{1}$ što ga tek čini spremnim za komparaciju s drugim sukladnim entitetima, u ovom slučaju s elaboracijom istog pojma u srpskoj srbističkoj književnoj historiografiji.

Ključne riječi: prosvjetiteljstvo, pučko prosvjetiteljstvo, jozefinizam, iluminizam, racionalizam, katolička obnova, modernizacija, hrvatska književna historiografija.

ovijest kroatističkog književnohistoriografskog interesa za hrvatsku književnu kulturu 18. stoljeća mogla bi se ugrubo podijeliti u tri faze. Prvu, nazovimo je tradicionalnom pozitivističko-kulturnopovijesnom, a koja traje do sredine prošlog stojeća, karakterizira-

\footnotetext{
Koncept pojedinačne kulture shvaćamo ovdje kao heurističko pomagalo, a ne kao realni povijesni entitet. Uostalom, prema uvjerljivom kriteriju za izdvajanje pojedinačnih književnih kultura - egzistenciji jedinstvenog jezika na kontinuiranom prostoru književne komunikacije - ono što bi se danas nazvalo hrvatskom književnosti u Habsburškoj Monarhiji u 18. stoljeću, može se motriti i kao dvije pojedinačne književnosti - slavonska štokavska književnost i kajkavska knjiženost Banske Hrvatske. U književnoj se historiografiji, još uvijek čvrsto ukorijenjenoj u tradicionalnoj filološkoj paradigmi, ta dva segmenta obično odvojeno obrađuju. Takav filološki esencijalizam čini nam se podjednako (ne)opravdanim kao i etnički, koji, primjerice, u isti koš trpa domaćeg pučkog pisca i našijenca iz elitnih europskih latinističkih krugova.
} 
ju pionirski radovi, ${ }^{2}$ fundamentalna istraživanja i kapitalne monografije ${ }^{3}$ te kritičko objavljivanje temeljnih djela. ${ }^{4}$ To posljednje nastavit će se i u sljedećoj fazi, ${ }^{5}$ koju ipak obilježava dominacija imanentističke paradigme (interes za estetske aspekte književnosti, koncept literarnosti kao differentia specifica umjetničke književnosti, formalni pristup književnom djelu), što rezultira dvjema uzajamno povezanim tendencijama: slabljenjem istraživačkog interesa za književnost 18. stoljeća i njezinom estetičkom diskvalifikacijom. ${ }^{6}$ Zanimanje za 18. stoljeće oživjet će u kulturološkom zaokretu 1990-ih godina, najprije u nekoliko znanstvenih simpozija posvećenih tom razdoblju i ključnim piscima ${ }^{7}$ te značajnim širenjem korpusa predmetne znanstvene literature. ${ }^{8} \mathrm{~S}$ obzirom na to da se još uvijek nalazimo u toj fazi istraživačkog odnosa prema 18. stoljeću, njezini spoznajni dometi nisu još valorizirani, a upravo to bi mogla biti i jedna od zadaća našeg projekta. Sve u svemu, po prirodi svog predmeta, istraživački je interes za književnost 18. stoljeća uvijek nadilazio estetske i formalno-književne aspekte, odnosno uključivao ideološke, političke i društvene uvjete književne proizvodnje.

\footnotetext{
Nikola ANDRIĆ Iz ratničke književnosti hrvatske (literarna slika XVIII. vijeka. Zagreb: A. Scholz. [pretisak Vinkovci: Privlačica, 1994]; Branko VODNIK, Slavonska književnost u XVIII. vijeku. Zagreb: M. Breyer, 1907. [pretisak Vinkovci: Privlačica, 1994]; ISTI, Povijest hrvatske književnosti. Knjiga I. Od humanizma do potkraj 18. st. Zagreb: Matica hrvatska, 1913; Josip MATASOVIĆ, Iz galantnog stoljeća: kulturnohistorijski fragmenti. Zagreb. [2. prošireno izd. Zagreb: Dora Krupićeva, 2008.]

3 Mirko DEANOVIĆ, „Odrazi talijanske akademije degli Arcadi preko Jadrana“. Rad JAZU 248/1933, 1-98; 250/1935, 1-125; Vladoje DUKAT, Sladki naš kaj: ogledi iz stare kajkavske književnosti. Zagreb: Hrvatski izdavalački bibliografski zavod, 1944; Tomo MATIĆ, Prosvjetni i književni rad u Slavoniji prije Preporoda, Zagreb: HAZU, 1945 [pretisak Vinkovci: Privlačica, 1994].
}

4 Do kraja Drugog svjetskog rata u ediciji „Stari pisci hrvatski“ (SPH) književnici 18. stoljeća izdavani su u kontinuitetu od knj. 22/1913 do knj. 28/1945, i to redom: Jerolim Kavanjin, Matija Antun Relković, Ignjat Đurđević, Antun Kanižlić, Antun Ivanošić, Matija Petar Katančić te Andrija Kačić Miošić.

5 U ediciji SPH kontinuitet je nastavljen s Titušem Brezovačkim (29/1951), Filipom Grabovcem (30/1951), Vidom Došenom (34/1969), te dubrovačkim preradama Molierèa (36-37/1972-73).

6 U 1970-im godinama dolazi ipak do kratkotrajne konjunkture interesa za 18. stoljeće. Osim sinteze Rafe BOGIŠIĆA, „Književnost prosvjetiteljstva“, Povijest hrvatske književnosti: Od renesanse do prosvjetiteljstva, knj. 3, (ur.) Marin Franičević, Franjo Švelec i Rafo Bogišić). Zagreb: Liber, Mladost, 1974, 293-383. Tu ulaze Zbornik zagrebačke slavističke škole III (1975) posvećen hrvatskoj književnosti i jeziku 18. stoljeća te 5. knjiga Dana hvarskog kazališta (1978).

7 „Hrvatski književni barok i slavonska književnost 18. stoljeća“, Osijek 1993; „Hrvatska književnost 18. stoljeća“, Prvi hrvatski slavistički kongres, Pula 1995; „Hrvatska književnost 18. stoljeća: tematski i žanrovski aspekti“", Dani hvarskog kazalista XXI/1995 i XXII/1996; „Fra Filip Grabovac u kontekstu hrvatske kulture“, Vrlika, 1996; „Matija Antun Relković i Slavonija 18. stoljeća“, Zagreb, Vinkovci, Davor 1998; „Znanstveni skup o Josipu Paviševiću“, Osijek, 2003; „Fra Andrija Kačić Miošić i kultura njegova doba“, Zagreb i dr., 2004. Još 1984. održan je u Novoj Gradiški znanstveni skup „Vrijeme i djelo Matije Antuna Reljkovića“, no knjiga je, u uredništvu D. Tadijanovića i J. Vončine i izdanju JAZU, objavljena tek 1991.

8 Neke od monografija i zbirki studija u kojima je isključivo ili znatnije prisutna književna kultura sjeverne Hrvatske u 18. stoljeću, često upravo njezin religiozni segment: Milovan TATARIN, Od svita odmetnici: rasprave o nabožnim temama u Slavoniji u 18. stoljeću. Split: Književni krug, 1997; ISTI, Zaboravljena Oliva: rasprave o hrvatskoj nabožnoj književnosti 18. stoljeća. Zagreb: Matica hrvatska, 1999; ISTI. Ljubavi nebeske, ljubavi zemaljske: prilozi hrvatskoj nabožnoj književnosti 18. stoljeća. Zagreb: Disput, 2007; Davor DUKIĆ, Poetike hrvatske epike 18. stoljeća. Split: Književni krug, 2002; Zlata ŠUNDALIĆ Kroz slavonske libarice: rasprave o nabožnoj književnosti u Slavoniji. Osijek: Ogranak Matice hrvatske u Osijeku, 2005; Ružica PŠIHISTAL „Problem slavonskog baroka u hrvatskoj znanosti o književnosti“", Ključevi raja: hrvatski književni barok i slavonska književnost 18. stoljeća, (prir. J. Matanović). Zagreb: Meandar, 49-72. 
U prenošenju književnopovijesnog znanja i oblikovanju kulturnog pamćenja putem kanonizacije pisaca i djela, odlučujuću ulogu imaju takozvane nacionalne (eventualno i regionalne) književnopovijesne sinteze. One, točnije njihov narativni tip, ${ }^{9}$ bile su u središtu naše istraživačke pozornosti pa ćemo se u ovom prilogu usredotočiti ponajprije na usporedbu u njima sadržanih koncepata prosvjetiteljstva. Nećemo, međutim, posve zanemariti ni problem uključivanja spoznaja iz drugih književnopovijesnih, uglavnom kraćih sintetskih tekstova - oni će se, kao i komparativni pogledi na različite književnopovijesne deskripcije nekih ključnih pisaca, uglavnom problematizirati u fusnotama, pri čemu će katkad biti napušteno kronološko načelo kojeg se drži glavnina osnovnog teksta.

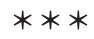

Prvu sveukupnu sintezu hrvatske ranonovovjekovne književne povijesti objavio je Branko Vodnik 1913. godine. Tek slabije poznavatelje Vodnikova opusa i književnopovijesnog prosedea te razvoja interesa za književnost 18. stoljeća može iznenaditi tvrdnja da se već u njegovoj knjizi mogu pronaći gotovo sva historiografska „opća mjesta“ o hrvatskoj književnosti 18. stoljeća. Te ćemo, do danas općeprihvaćene, uvide taksativno parafrazirati:

- središte prosvjetiteljstva je sjeverna Hrvatska (Slavonija), dok istodobno književni rad u Dubrovniku općenito „propada“;

- pisci-svjetovnjaci i djela svjetovna sadržaja u 18. st. od posebne su važnosti za književnopovijesna istraživanja, ali iz njih se ni vjerskopoučna literatura (primjerice, kajkavska religiozno-moralna književnost) ne isključuje, niti posebno odvaja;

- postoji relativno oštra tipološka/poetička granica između prve i druge polovice stoljeća, a u toj podjeli M. A. Relković ima status prijelomnog pisca: on je „prvi slavonski pisac svjetovnjak“ i prvi koji je u slavonsku književnost „uveo prosvjetiteljstvo na osnovi racionalističkoj i demokratskoj, pripravivši tako tlo prosvjetiteljskim idejama Josipa II.“; ;

- jozefinizam je jedna od varijanti prosvjetiteljstva (u Vodnikovoj interpretaciji on je oblik „ekstremnog prosvjetiteljstva");

- hrvatsku književnu kulturu 18. stoljeća karakterizira neprihvaćanje radikalnog (deističkog i ateističkog) prosvjetiteljstva;

- u 18. stoljeću javljaju se protonacionalističke tendencije: početci jezične standardizacije i širenje narodnog imena. ${ }^{11}$

Prosvjetiteljstvo, kao opći pojam, u Vodnikovoj se Povijesti eksplicitno ne definira. Njime se obuhvaćaju: vjersko-poučna pučka literatura (dominira u sjevernoj Hrvatskoj do sredine stoljeća), racionalistički i demokratski usmjeren književni rad na narodnom jeziku

\footnotetext{
Drugi tip književnopovijesnih sinteza čini leksikonska/enciklopedijska literatura, bilo da je riječ o tradicionalnim leksikonima/enciklopedijama pisaca, djela i pojmova, ili o takozvanim postmodernim književnim enciklopedijama, kako ih naziva David PERKINS - zbirkama eseja više autora o temama koje su relevantne u trenutku opisivanja dotične književne povijesti (Is Literary History Possible? Baltimore, London: The Johns Hopkins University Press, 1992 , 53-60). Toj bi varijanti trebao pripadati i završni produkt našeg projekta pa je i ovo kritičko čitanje narativnih sinteza svojevrsno „konceptualizirano nepovjerenje prema prethodnicima“.

10 Branko VODNIK, Povijest hrvatske književnosti, 346.

11 Isto, 365.
} 
(Relković), propagiranje jozefinskih ideja (A. T. Blagojević, J. Krmpotić) te znanstvena literatura na latinskom (dubrovački latinisti inspirirani „strujom prosvjetiteljstva“, pavlinski pisci u kajkavskoj književnosti). Demokratičnost, racionalizam i sekularizacija temeljni su prosvjetiteljstvu (implicitno) subordinirani pojmovi koji se objedinjeno konkretiziraju samo u djelu M. A. Relkovića.

Monografija Tome Matića Prosvjetni i književni rad u Slavoniji prije preporoda (1945) jedina je sinteza regionalne književne povijesti u ovom kritičkom pregledu, no njezin je informativni kapacitet za problematiku našeg projekta znatno veći od drugih, „nacionalnih“ ili višeregionalnih sinteza. Pisana bez esteticističkih ograda, kao sveobuhvatan pregled slavonske književne kulture 18. i početka 19. stoljeća, organiziran prema žanrovsko-tematskom kriteriju, Matićeva je knjiga i danas temeljno polazište u istraživanju prosvjetiteljskih tendencija u slavonskoj književnosti. Na razini općih uvida ona u odnosu na Vodnikovu knjigu ne donosi ništa novo, ali te uvide (vezane uz slavonski prostor) potkrepljuje velikom količinom primjera, upućujući tako i suvremenog istraživača u najrelevantniju izvornu književnu građu. Za ilustraciju može poslužiti napomena o važnosti isusovca Josipa Milunovića, pisca kojeg Vodnik ne spominje, a koji u knjizi Šest nedilja na poštenje s. Alojžije Gonzage (Zagreb 1759), tri godine prije Relkovićeva Satira, ističe korist opismenjivanja puka. ${ }^{12}$ Vodnikova postavka o razlikama dviju polovica 18. stoljeća jedna je od provodnih niti Matićeve knjige, realizirana ovdje u dihotomiji vjerskalsvjetovna prosvjeta. Matić, dakle, širim, demokratičnijim $\mathrm{i}$ istraživačkom predmetu primjerenijim pojmom prosvjete zamjenjuje pojam prosvjetiteljstva.

U isto vrijeme kad i Matićeva knjiga, objavljena je i Kombolova Poviest hrvatske književnosti do narodnog preporoda (1945), sve donedavno temeljni akademski priručnik za studij hrvatske ranonovovjekovne književnosti. Teza o Kombolu estetskom elitistu, kročeancu, oštrom kritičaru književne baštine, ulazi u krug stereotipnih tvrdnji o hrvatskoj književnoj historiji. Premda bi minucioznije iščitavanje sadržaja i strukture Kombolova kapitalnog djela moglo taj stereotip dovesti u pitanje, za potrebe ovog priloga on se može uzeti kao više-manje točan. Naime, u Kombolu nije teško prepoznati ranog zagovaratelja književnopovijesnog imanentizma - njegovo razumijevanje i prezentacija nacionalne književnosti zato je i moglo biti relevantno od 1960-ih do 1990-ih godina; njegova je Poviest iz 1945. preteča dvaju zbornika o odnosu hrvatske i (zapadno)europskih književnosti iz 1970-ih. ${ }^{13}$ U takvom pristupu književnost osamnaestog stoljeća nije mogla dobro proći; Vodnikovu postavku o propadanju dubrovačke književnosti tog vremena Kombol je sintagmom-podnaslovom „književnost bez obnavljanja“ dodatno elaborirao i proširio na sve hrvatske pokrajine. Vjersko-prosvjetni rad u njegovoj knjizi ne prelazi razinu taksativnog spominjanja; Kombol nema potrebu širenja pojma prosvjetiteljstva u pokušaju da se njime obuhvate $\mathrm{i}$ književne i kulturne pojave prve polovice 18. st. Prosvjetiteljstvo („prosvjećenost“) njemu, prije svega, ostaje skup ideologema elitne zapadne građanske kulture („vjerovanje u raci-

12 Evo numeričkih podataka koji potkrepljuju postavku o kulturnopovijesnoj informativnosti Matićeve knjige. Od 42 slavonska pisca koje u bibliografskom dodatku na kraju knjige navodi Matić, Vodnik spominje samo njih polovicu. Među nespomenutima sedam je pisaca objavljivalo svoja djela u 19. st. pa ih je Vodnik mogao izostaviti i zbog različito postavljenih vremenskih granica (Grgur Ćevapović, Adam Filipović, Antun Mihalić, Josip Mihalić, Antun Nagy, Karlo Pavić, Martin Pustaić), no ostalih je 14 djelovalo upravo u 18. stoljeću (Juraj Barjaktari, Daniel Emir Bogdanić, Ivan Grličić, Nikola Kesić, Đuro Kordić, Petar Mandikić, Josip Milunović, Franjo Ksaver Pejačević, Jakob Pejačević, Franjo Sebastijanović, Đuro Sertić, Blaž Tadijanović, Antun Josip Turković, Antun Josip Vlašić).

13 Hrvatska književnost prema evropskim književnostima, (ur. Aleksander Flaker i Krunoslav Pranjić), Zagreb: Liber, 1970; Hrvatska književnost u evropskom kontekstu, ur. Aleksander Flaker i Krunoslav PRANJIĆ, Zagreb: ZZK, 1978. 
onalnu objašnjivost i popravljivost svijeta“; snošljivost; „kritika tradicionalnih ustanova i vjerovanja“) kao misaone podloge Francuske revolucije. Ne skrivajući žudnju pripadanja zapadnom kulturnom krugu, Kombol neće, naravno, moći poreći zaostajanje svog istraživačkog predmeta, ali će tim radije isticati one pisce koji su se svojim stavovima katkad približili zapadnom iluminizmu (I. Lovrić, donekle i A. B. Krčelić). Nove književne i kulturne tendencije na hrvatskom sjeveru Kombol će podvesti pod „terezijanski racionalizam“ kao „malograđanski pitomiji odraz radikalnije zapadnoeuropske prosvjećenosti“ ${ }^{14}$ Gubitak „aristokratskog artizma“ u književnosti 18. stoljeća kompenzirat će se, iz Kombolove teleološko-nacionalne perspektive, istodobnim „kulturnim izjednačavanjem naših pokrajina“. ${ }^{15}$

Godinu dana prije Matićeve i Kombolove knjige objavljena je u Zagrebu, u vrlo raskošnom izdanju, kako i dolikuje kapitalnom djelu nacionalne kulture, sinteza cjelokupne hrvatske književnosti Slavka Ježića. I dok su Matićev i Kombolov pregled, premda također nastali i objavljeni u NDH, bili dobro recipirani u vremenu poslije rata, Ježićeva je knjiga dugo vremena bila izložena svojevrsnom tihom bojkotu, da bi u 1990-ima doživjela rehabilitaciju i ponovljeno izdanje. ${ }^{16}$ Poglavlje relevantno za ovu raspravu nosi naslov „Racionalizam i narodno prosvjećivanje (XVIII. stoljeće)“ (str. 163-185). Prvi pojam vezan je uz europske temelje „vijeka prosvjećenosti“ (Descartes), na čemu počivaju i onodobne ideje „o vjerskoj, narodnoj i rasnoj toleranciji (snošljivosti)“" te kritika crkvenih i državnih institucija koja je dovela do Francuske revolucije (str. 163). Drugi pojam ipak ima ključno značenje u Ježićevu regionalno strukturiranom, kratkom pregledu hrvatske književnosti osamnaestog stoljeća. U njegovu su kanonu, svojevrsnom kombinacijom kriterija demokratične angažiranosti i žrtvovanja za opće interese, posebno dobro prošli F. Grabovac, A. Kačić Miošić i Mateša Kuhačević, ${ }^{17}$ dok je Relković zadržao središnje mjesto u slavonskoj dionici, kao „najtipičniji i najpopularniji prosvjetiteljski pisac“. Slavonske je pisce Ježić podijelio u dva tabora: prosvjetiteljski (M. A. Relković, A. T. Blagojević, J. Krmpotić, V. Došen, donekle i M. P. Katančić) i antiprosvjetiteljski (A. Ivanošić, J. Stojanović). S druge strane, u istodobnoj književnosti Banske Hrvatske Ježić vidi kontinuitet katoličke obnove, a „neke prosvjetiteljske crte" uočava tek u latinskom opusu A. B. Krčelića, dok od kajkavskih književnika epitet prosvjetitelja može ponijeti samo T. Mikloušić. Čak i u dramskim tekstovima središnjeg kajkavskog pisca tog razdoblja, T. Brezovačkog, Ježić uočava antiprosvjetiteljske, antijozefinske ideje. ${ }^{18} \mathrm{U}$ Ježićevu je pregledu jozefinizam jedan od ključnih pojmova razdo-

14 Mihovil KOMBOL, Povijest hrvatske književnosti do preporoda, Zagreb: Matica hrvatska, 1961, 370.

15 Isto, 341.

16 V. uvodni tekst Tihomila MAŠTROVIĆA („Riječ urednika“) u Zborniku o Slavku Ježiću, ur. Tihomil MAŠTROVIĆ, Zagreb 1997, 5-6, te prilog Alojza JEMBRIHA „Referencijalna zastupljenost Ježićevih djela u povijestima hrvatske književnosti“" u istoj knjizi, 191-196.

17 Kuhačeviću je Branko VODNIK posvetio tek jednu rečenicu nabrojivši samo tematiku njegovih pjesama (str. 364). Mihovil KOMBOL pak, kao i prije njega Ježić, detaljnije prikazuje Kuhačevićev opus, ali bez stilskoperiodizacijskih ili idejnih atributa, ističući tek piščevo domoljublje i nesretnu sudbinu usporedivu s Grabovčevom (Povijest hrvatske književnosti do preporoda, 359-362). Slično će biti i u Bogišićevu tekstu („Književnost“, 324-326), a začuđuje da će na Kuhačevića zaboraviti Jelčić u svom, s obzirom na to da je riječ o sintezi cjelokupne hrvatske književnosti, relativno iscrpnom prikazu 18. stoljeća. Za našu problematiku važno je podsjetiti se da je taj senjski vojnik i pjesnik bio podanik Habsburške Monarhije i jedan od najistaknutijih hrvatskih protivnika „rane modernizacije“: u dugogodišnju je tamnicu dospio zahvaljujući angažiranom protivljenju carskim vojnim reformama, a u pjesmi „Narikovanje staroga Senja vrh mladoga Senja po vili Slovinki“ obrušio se na prodor pomorske trgovine koja je mijenjala stari vojnički identitet njegova grada.

18 VODNIK je Brezovačkog smjestio u neposredno predpreporodno razdoblje, dakle izvan granica istraživačkog interesa svoje knjige (imao je on namjeru napisati cjelokupnu povijest hrvatske književnosti, ali ga je u tome omela prerana smrt). KOMBOL je pak u idejnoj ocjeni opusa T. Brezovačkog nešto nijansiraniji: ističe piščeve prigodne 
blja, a indikativno je da je pored A. T. Blagojevića posebno istaknut Istranin Josip Voltić Voltiggi, koji je svoje jozefinske ideje pretočio u djelo na talijanskom jeziku, Lettere vienesi (1789) (str. 174).

Sinteza „višeregionalne“ književne povijesti Krešimira Georgijevića Hrvatska književnost od 16. do 18. stoljeća u sjevernoj Hrvatskoj i Bosni (1969) u stručnim je krugovima imala status „nadopune Kombola“. No, četvrt stoljeća mlađa knjiga ne razlikuje se samo po premještenu istraživačkom fokusu, premda možda upravo njemu i duguje svoje metodološke specifičnosti. Naime, po njima Georgijević je bliži Vodniku, a osobito Matiću, nego Kombolu. Štoviše, ni u jednoj starijoj pa ni mlađoj sintezi hrvatske ranonovovjekovne književne povijesti nije književna proizvodnja do te mjere kontekstualizirana u društvenu strukturu i politička zbivanja, ni jedno djelo istog književnohistoriografskog žanra nije toliko posezalo za društvenopovijesnom i kulturnopovijesnom literaturom i izvorima. Doduše, krug takve literature i izvora često je vrlo uzak; Georgijević čitava potpoglavlja svoje knjige temelji katkad na samo jednom naslovu pa njegovo djelo i danas ima status vrlo solidnog sveučilišnog udžbenika, ali i tek polaznog priručnika za ozbiljnija književnopovijesna istraživanja. ${ }^{19} \mathrm{I}$ pored toga, Georgijevićeva je knjiga prva u nizu ovdje razmatranih sinteza u koju je, barem implicitno, problemski inkorporiran i drugi dio ključne sintagme iz naslova našeg kolokvija - modernizacija. Ogleda se to ne samo u interesu za produkciju praktičnih gospodarskih knjižica namijenjenih slavonskim seljacima, prisutnom već kod Matića, te u uobičajenoj usporedbi domaćih i zapadnih prilika, nego i u produktivnoj recepciji novijih ekonomskih čitanja Relkovićeva djela. ${ }^{20}$ Pored elaboracije već potvrđenih generalizacija o hrvatskoj/ slavonskoj književnosti 18. stoljeća (blaža varijanta prosvjetiteljskih ideja, duboka razlika dviju polovica stoljeća, Relković kao prijelomnica), Georgijević nudi i neka nova tumačenja. U omjeravanju hrvatske kulture sa Zapadom ističe kako plemićki stalež još donekle može slijediti zapadne uzore (Matasovićevo "galantno stoljeće“), ali upravo nepostojanje razvijene građanske klase onemogućuje realizaciju (revolucionarno-)prosvjetiteljskih ideja odozdo pa hrvatskoj kulturi ostaje tek institucionalno dirigirani prosvijećeni apsolutizam (jozefinizam). No, najvažnija posebnost Georgijevićeva tumačenja književnosti 18. stoljeća tiče se njezine religiozne komponente - Georgijević, naime, još odlučnije nego Ježić prije njega, napušta model kontinuiranog književnog razvitka, pa u religioznoj književnosti prve (ali i druge) polovice 18. stoljeća ne vidi samo ranoprosvjetiteljska nastojanja za širenjem vjere putem širenja pismenosti i knjige, nego uočava i „kronični anakronizam“ tj. istovremenost raznovremenog, točnije elemente katoličke obnove (u njegovoj terminologiji protu-

tekstove uperene protiv ideja francuske revolucije i „vjerski liberalne prosvijećene filozofije“, ali i njegovu racionalističku, pragmatičku kritiku poroka vlastitog vremena koji onemogućuju postizanje općeg dobra i društvenog sklada (Povijest hrvatske književnosti do preporoda, 407-410). Georgijević će već napomenuti kako „prosvjetiteljstvo [Brezovačkog] ima utilitarno-didaktičan karakter" (Hrvatska književnost, 282), a u skici idejnog profila kajkavskog pisca uglavnom će potvrditi Kombolove uvide (vjerska tolerancija, ali ne i ateizam; oslikavanje društva, ali ne i izrazitije oštra društvena kritika, Isto, 290-291). Na istom će tragu, ali manje akribičan, biti i Bogišić („Književnost“, $364-$ 370), dok će Nikica KOLUMBIĆ u sintetskom prikazu „hrvatske prosvjetiteljske drame“, prihvaćajući Bogišićevo maksimalističko određenje hrvatskog prosvjetiteljstva (a ne citirajući Ježića!), pronaći prosvjetiteljske crte, odnosno moralizatorsko-didaktičke elemente, čak i u religioznoj drami Sveti Aleksij (1978:104). Zanimljivo je da će se Frangeš u ovom problemu vratiti Vodnikovoj periodizaciji te Brezovačkog smjetiti u kontekst „pretpreporodnih gibanja“.

19 U korpus najvažnijih Georgijevićevih izvora i literature za rekonstrukciju društvenog, kulturnog i idejnog konteksta sjevernohrvatske književnosti 18. stoljeća ulaze: F. W. TAUBE, Historische und geographische Beschreibung des Königreiches Slavonien und des Herzogtumes Syrmien, I-III, Wien 1777-1778; Adam Baltazar KRČELIĆ, Annuae sive Historia. Zagreb: JAZU, 1952; Josip MATASOVIĆ, Iz galantnog stoljeća; ISTI, Die Briefe des Grafen Sermage aus dem Siebenjährigen Kriege, Zagreb 1923; ali i Tomo MATIĆ, Prosvjetni i književni rad.

20 Rudolf BIĆANIĆ, Počeci kapitalizma u hrvatskoj ekonomici i politici. Zagreb: Školska knjiga 1952, 23-64. 
reformacije) pa i srednjovjekovne književne tradicije duboko u epohi prosvjećenosti. Protureformatorske tendencije Georgijević ponajviše vezuje uz polemičku literaturu o raskolu i pravoslavlju, a Antun Kanižlić, inače jedno od prvih imena slavonskog književnog kanona, primjer mu je izrazito anakronog pisca, ogrezlog u „srednjovjekovno praznovjerje“. Njegovi prosvjetiteljski antipodi bili bi prije svih M. A. Relković i A. T. Blagojević.

Rafo Bogišić, autor dionice o 18. stoljeću u trodijelnoj povijesti hrvatske ranonovovjekovne književnosti (Povijest hrvatske književnosti: Od renesanse do prosvjetiteljstva, knj. 3 , 1974) prvi je od domaćih pisaca književnopovijesnih sinteza koji već u naslovu rabi termin prosvjetiteljstvo („Književnost prosvjetiteljstva“). Podnaslov njegova teksta, „Književnost učenih", sugerira kako je kategorija učenosti (znanstvenosti) temeljni subordinirani pojam pojmu prosvjetiteljstva, čime se u nj uključuje i latinistički segment književne kulture. Bogišićev tekst u cijelosti, unatoč tome što mu je teško odrediti pripadajuću književnohistoriografsku paradigmu, ipak odražava temeljne tendencije hrvatske književne historiografije 1970-ih godina: vjeru u stilskoperiodizacijsko pojmovlje kao nasljeđe imanentizma i žudnju za uključenosti u zapadni književni krug, sa svim popratnim izrazima i postupcima karakterističnim za takvu etnocentričnu književnopovijesnu perspektivu. To potonje ogleda se, primjerice, u stereotipu o nepovoljnim povijesnim okolnostima (Bogišić govori o kolonijalnom karakteru mletačkih i austrijskih vlasti u hrvatskim zemljama!) koje onemogućuju recepciju zapadnih ideja. Poput Kombola, i Bogišić će elaborirati zaostajanje za zapadnim iluminizmom, ali istodobno i isticati svaki njegov trag u domaćoj kulturi, pa makar se radilo i o osviještenom odbacivanju (A. Ivanošić, J. Stojanović, J. Malevac, J. Mulih). Od svih svojih prethodnika Bogišić je najdalje otišao u procjeni protonacionalnointegracijskih dosega hrvatske književnosti 18. st.: i on je istaknuo povezivanje hrvatskih pokrajina i rad na standardizaciji jezika, a u istom je slijedu tumačio i onodobni interes za narodnu tradiciju. Tako je i istaknute hrvatske pisce 18. stoljeća uključio u konstruirani kanon nacionalnog književnog angažmana, koji započinje glagoljašima, a nastavlja se Marulićem i Zoranićem. Bogišićev širok i dobrohotno demokratičan pojam hrvatskog prosvjetiteljstva obuhvatio je stoga i terezijansko-jozefinski prosvijećeni apsolutizam i sva domaća prosvjetna, „didaktičko-moralizatorska" nastojanja - čak i Cvit razgovora naroda i jezika iliričkoga aliti rvackoga (1747) dalmatinskog franjevca Filipa Grabovca, knjigu koja bi, već zbog u njoj izrazito izražene vjerske netolerantnosti, u svakoj književno razvijenijoj europskoj sredini bila laka meta upravo prosvjetiteljskih kritika. ${ }^{21}$ Ipak, valja priznati, da u religioznoj književnosti 18. stoljeća, posebice kajkavskoj (Š. Zagrebec, Š. Fuček, H. Gašparoti, J. Mulih) i književnosti bosanskih i dalmatinskih franjevaca (S. Margitić, F. Lastrić, T. Babić, L. Šitović), Bogišić nije vidio samo "prosvjetiteljsko-vjerski pokret“ nego i nastavak katoličke obnove. ${ }^{22}$ Štoviše, najopsežnije opisano književno djelo u Bogišićevu pregledu upravo je Kanižlićeva Sveta Rožalija, „najznačajnije djelo katoličke protureformacije u sjevernoj Hrvatskoj“. ${ }^{23}$

21 R. BOGIŠIĆ, „Književnost“, 314. V. Dunja FALIŠEVAC, „Filip Grabovac u kontekstu protureformacije i katoličke obnove“, Fra Filip Grabovac u kontekstu hrvatske kulture, ur. N. Strukan. Vrlika: Poglavarstvo grada Vrlike, Matica hrvatska Vrlika, Matica hrvatska Sinj, 1998, 47-60.

22 R. BOGIŠIĆ, „Književnost“, 1974, 333.

23 Isto, 339-342. Svoje osnovne postavke o hrvatskoj književnosti 18. stoljeća BOGIŠIĆ je sažeo u predavanju za strane slaviste održanom u ljeto 1975. godine i objavljenom u III. godištu Zbornika Zagrebačke slavističke škole. Suprotno od BOGIŠIĆA, Ivan SLAMNIG u kratkoj sintetskoj studiji o hrvatskoj književnosti 18. stoljeća ponudio je minimalističko shvaćanje domaćeg prosvjetiteljstva, za koje je istaknuo kako „nije uspjelo nadrasti Crkvu“ (osim u slučaju Ivana Lovrića, padovanskog studenta i pisca na talijanskom jeziku). U Kačićevu je opusu Slamnig vidio stapanje katoličke obnove i prosvjetiteljstva, a Relkovićev Satir prema njemu „pripada subliteraturi pučkih poučnih priručnika, godišnjaka i kalendara koja nije vezana uz neku epohu ili stilsku formaciju“ (283). Takvu stilsko-idejno-periodizacijsku 
Jedini sintetski kroatistički književnohistoriografski poduhvat u 1980-ima bila je Povijest hrvatske književnosti Ive Frangeša. U proučavanju književnosti 18. stoljeća ta knjiga ne samo da nije napravila novi iskorak, nego nije ni ocrtala postojeće stanje istraženosti. To je bio danak Frangešova izrazito esteticističkog pristupa (u čemu je taj književni povjesničar daleko nadišao jednog Kombola), ali i njegova impresionističkog esejiziranja. Ne samo da je ovdje (upravo zbog estetskih kriterija) riječ o razmjerno najkraćem prikazu hrvatske književnosti 18. stoljeća, nego je, što je za našu tematiku osobito važno, književnost sjeverne Hrvatske prilično zapostavljena: jozefinizam se tek spominje, ali detaljnije ne elaborira, a od slavonskih pisaca spomenuti su Blagojević i Došen, kratko obrađeni Relković i Kanižlić, a tek nešto malo opsežnije Katančić. Kvantitativna zastupljenost odražava, naravno, autorovo poimanje važnosti dotičnih književnika pa je u tom smislu središnja književna figura 18. stoljeća Andrija Kačić Miošić, kojemu je posvećeno više od polovice poglavlja „Racionalizam. Predromantizam“. Frangešova metodološka nebriga ogleda se i u terminološkoj površnosti. Već na početku ističe kako su racionalizam, prosvjetiteljstvo i prosvjećenost sličnoznačnice te kako različita terminologija upućuje na regionalne posebnosti pa je tako za sjevernu Hrvatsku karakterističan germanski jozefinizam, a za južnu iluminizam koji dolazi s Apeninskog poluotoka, iz Francuske i Švicarske. I premda na dominantnu važnost pojma racionalizam upućuje sam naslov, a donekle i njegova kasnija frekventnost (Kačićevo „racionalističko zanimanje za historiju“, Bajamontijeva ideja „racionalističkog djelovanja u narodu“), ta se, u osnovi idejno-svjetonazorska, odrednica stavlja u istu ravan s etabliranim književnopovijesnim pojmovljem (neoklasicizam, predromantizam) ili, u slučaju opisa Relkovićeva opusa, izjednačuje s pojmom prosvjetiteljstva. Frangeš, naravno, ne osjeća potrebu da bilo koji od tih termina posebno definira ili barem uputi na kontrastivne semantičke razlike.

Treća i nažalost posljednja u nizu knjiga o starijoj hrvatskoj književnosti višesveščane Povijesti hrvatske književnosti Slobodana Prosperova Novaka, s naslovom Od Gundulićeva "poroda od tmine" do Kačićeva "Razgovora ugodnog naroda slovinskoga" iz 1756 (1999), zaustavila se, dakle, prije Relkovićeva Satira. Novak je neortodoksan književni povjesničar, koji samosvjesno odustaje od prepoznatljivih književnopovijesnih kompozicijskih postupaka, a svoju sintezu uglavnom gradi nizom eruditsko-esejističkih interpretacija pisaca (pojedinačnih sudbina) i njihovih djela. Zanimljiv je njegov izbor relevantnih stilskoperiodizacijskih kategorija, što ih donosi u podnaslovu knjige: „Rano novovjekovlje: katolička obnova i rano prosvjetiteljstvo", pri čemu se prva sintagma odnosi na čitavo knjigom obuhvaćeno razdoblje, druga na 17. stoljeće, a treća na prvu polovicu 18. stoljeća. Katolička obnova kao kulturnopovijesni/duhovnopovijesni pojam zamjena je za dugo vremena nezamjenjiv pojam barok, dok se pojam prvo prosvjetiteljstvo ovdje rabi prvi put u prikazu hrvatske knji-

identifikaciju Relkovićeva djela neće prihvatiti kasniji povjesničari književnosti, osim donekle Pavla PAVLIČIĆA, koji će se upravo preko kritike maksimalističkog određenja prosvjetiteljstva kao zasebnog perioda hrvatske književnosti te na tragu Slamnigove postavke o pučkoj književnosti kao fenomenu duga trajanja, zapitati „nisu li ideje evropskog prosvjetiteljstva, kao filozofskog i kao literarnog pokreta, u nas, zbog specifičnosti naše situacije, zadobile osobit oblik, pa se tako realizirale prije svega u žanrovima i žanrovskom sistemu pučke literature." (Kamo pripada Reljkovićev Satir?", Vrijeme i djelo Antuna Reljkovića: znanstveni skup Nova Gradiška, 25.-27. listopada 1984., ur. Dragutin Tadijanović i Josip Vončina. Osijek: JAZU, 1991, 94). Takvu sudbinsku povezanost pučkog i prosvjetiteljskog u hrvatskoj književnosti sredine 18. st. vidjet će i Miroslav ŠICEL. V. Povijest hrvatske književnosti XIX. stoljeća. Knjiga I., Od Andrije Kačića Miošića do Augusta Šenoe (1750-1881). Zagreb: Naklada Ljevak, 2004.). Zlatko POSAVEC će pak pobrojati što nedostaje Relkoviću u odnosu na zapadno prosvjetiteljstvo: „nema govora o slobodi, nema vjerske tolerancije, nema Rousseauovog tipa mišljenja o vlasti, suverenitetu i narodu.““(,Reljković i estetika“, Vrijeme i djelo Antuna Reljkovića: znanstveni skup Nova Gradiška, 25.-27. listopada 1984., ur. D. Tadijanović i J. Vončina. Osijek: JAZU, 1991, 107). 
ževne povijesti. Doduše, njegova primjena na slavonsku dionicu hrvatske književnosti ne donosi ništa novo - Novak tu njime pokriva sva ona prosvjetna nastojanja koja su i prije njega isticali Vodnik, Matić i Georgijević. Mali književnopovijesno-revolucionarni obrat događa se u Novakovoj primjeni tog pojma na književnost Dalmacije i Dubrovnika, što za naš projekt nije od izravne važnosti, ali pruža zahvalan komparativni materijal. Spoznajama iz Deanovićeve studije o primorskim akademijama $(1933,1935)$ poslužio se već Kombol, no Novak je stari činjenični materijal radikalno interpretirao. Za nj su, naime, institucije poput dubrovačke Akademije Ispraznijeh ili splitske Ilirske akademije središta hrvatskog iluminizma, mjesta u kojima samoorganizirana elita nastoji realizirati sve ono što se u književnoj historiografiji prepoznalo kao obilježja domaćeg prosvjetiteljstva: interes za narodnu tradiciju i narodni jezik, težnje prema racionalizmu, sekularizaciji i demokratičnosti u kulturi, protonacionalno-integracijski program, pa čak i „,duh novog liberalizma“. ${ }^{24}$ I premda bi se u Novakovoj knjizi pronašlo i proturječnih teza, a pogotovo kritičkih tonova o nacionalnoj književnoj baštini, ona je ipak najoptimističniji rezime o odnosu hrvatskog i (zapadno)europskog prosvjetiteljstva.

Takvim usporedbama domaćih i zapadnoeuropskih književnih postignuća nije opterećena Povijest hrvatske književnosti Dubravka Jelčića. ${ }^{25}$ Kroatocentrična se perspektiva knjige otkriva i u prikazu 18. stoljeća, već pri samom početku, u razmjerno opširnom portretu Pavla Rittera Vitezovića, osobito isticanjem njegova pankroatizma. U daljnjem tekstu, osim donekle u kratkom prikazu Grabovčeva djela i sudbine, autor, naravno, neće moći ispisati povijest književnosti samo na temelju razvoja nacionalne ideje. Štoviše, njegov je pristup i dalje u duhu imanentističke paradigme, na što upućuje i naslov poglavlja („,Stilski pluralizam 18. stoljeća") pa se osim dominantnog prosvjetiteljstva na prikladnim mjestima spominju još i barok, klasicizam, rokoko i predromantizam. Prosvjetiteljstvo u Jelčićevoj knjizi dobiva, kao i kod Bogišića i Novaka, nacionalni atribut, no bez eksplicitnih određenja te specifičnosti. Iz disperzije termina može se posredno zaključiti da Jelčić barata maksimalističkom varijantom pojma, koji obuhvaća Relkovićeva Satira kao „kultnu knjigu hrvatskog prosvjetiteljstva“, Grabovca i Kačića kao „pučke prosvjetitelje“, „bečko terezijanskojozefinsko prosvjetiteljstvo“ A. T. Blagojevića pa čak i „katoličko prosvjetiteljstvo“, doduše vezano uz jednog pisca 19. stoljeća (M. Jaića). Jelčić zaključuje kako je „prosvjetiteljstvo u panonskom dijelu Hrvatske odigralo istu ulogu kao renesansa u jadranskoj, a reformacija u sjeverozapadnoj (kajkavskoj) Hrvatskoj" (str. 126). ${ }^{26}$

Povijest hrvatske književnosti XIX. stoljeća Miroslava Šicela, unatoč svojemu naslovu, zanimljiva je za završetak našeg kronološki koncipiranog pregleda. Naime, prva knjiga Šicelove Povijesti nosi naslov Od Andrije Kačića Miošića do Augusta Šenoe (1750-1881) (2004). Doduše, naslovom obuhvaćenoj drugoj polovici 18. stoljeća posvećeno je svega nekoliko prvih

${ }_{24}$ Slobodan Prosperov NOVAK, Povijest hrvatske književnosti, knj. 3. Od Gundulićeva "poroda od tmine“ do Kačićeva „Razgovora ugodnog naroda slovinskoga“ iz 1756. Zagreb:Antibarbarus 1999, 614.

25 Prvo je izdanje knjige objavljeno 1997. godine, a „drugo, znatno prošireno izdanje“ 2004 . S obzirom na to da je do „znatnog proširenja“ došlo i u dionici o 18. stoljeću, u ovom je radu obrađujemo poslije Novakove knjige.

26 Na jednom mjestu kao da odjekuje lektira FRANGEŠOVE Povijesti - Matija Antun Relković dobiva atribut „najpotpunijeg i najpopularnijeg pisca hrvatskog racionalizma“. Ivo FRANGES, Povijest hrvatske književnosti. Zagreb Ljubljana: Nakladni zavod MH, Cankarjeva založba. 123. 
stranica i inače kratkog poglavlja „Stvaralaštvo dopreporodnog razdoblja“ (str. 14-30), jer autor nije ni imao namjeru opisivati književnost 18. stoljeća uobičajenom književnopovijesnom naracijom. Tih 50 godina i ime makarskog pisca dospjeli su u naslov samo zbog Šicelove, pomalo polemički intonirane, postavke o granicama prosvjetiteljstva u hrvatskoj književnosti. ${ }^{27}$ Šicel, dakle, u hrvatskoj književnosti prve polovice 18. stoljeća primjećuje pluralizam starijih književnih stilova (petrarkizma, baroka, rokokoa, klasicizma), ali ne i prosvjetiteljstvo, koje on definira dvjema temeljnim karakteristikama: „didakticizmom i odgojnom funkcijom pisane riječi “ ${ }^{28}$ Zanemarujući još od Vodnika prisutnu postavku o dvije različite polovice 18. stoljeća, Šicel čitavom nizu svojih prethodnika predbacuje olako protezanje periodizacijske kategorije prosvjetiteljstva, odnosno racionalizma, na čitavo stoljeće. ${ }^{29}$ No, kao i većina starijih povjesničara, i on u Kačićevu i Relkovićevu djelu vidi početak prosvjetiteljstva u hrvatskoj književnosti. S druge strane, a u tome je njegov originalniji doprinos periodizaciji hrvatske književnosti, gornju granicu pomiče sve do preporoda/ilirizma. Naime, Šicel „utilitarne, didaktičke, odgojno-moralne“ tendencije ne vidi samo kod kajkavskih pisaca na prijelazu stoljeća (T. Brezovački, T. Mikloušić, J. Lovrenčić), nego i kod A. Mihanovića, Lj. Gaja, I. Derkosa i drugih koji su u prvim desetljećima 19. st. težili „obrani od odnarođivanja, odnosno stvaranju temeljnih pretpostavki za konstituiranje moderne hrvatske nacije“. Šicelova logika odnosa stilskoperiodizacijskih kategorija najbolje se ogleda u njegovu određenju žanra budnice za koji tvrdi da „nije ništa drugo nego racionalistički, predromantičarski oblik prosvjećivanja - i ta činjenica, ti procesi, suprotni onim europskim, predstavljaju simbiozu, a ne razlaz romantizma s klasicizmom." (str. 21)

Koncept prosvjetiteljstva poput Šicelova dopušta razdvajanje dviju razina: jedne društveno-funkcionalne/kulturološke, druge estetičko-stilske. Kao i obično kad je riječ o stilsko-periodizacijskim kategorijama, opreku stil ili ideologija nikad nije moguće riješiti bez ostatka, tvrdeći da su, primjerice, barok i rokoko „ideološki prazni“ umjetnički stilovi, a klasicizam i romantizam nisu. No, uz kritički, više „nominalistički“ nego „realistički“ pristup periodizacijskom pojmovlju, ipak se čini mogućim zadržati predloženu bipolarnu klasifikaciju, prema kojoj bi za razdoblje koje je u središtu naših interesa prvoj kategoriji pripadali pojmovi katolickka obnova i prosvjetiteljstvo, a drugoj barok, klasicizam, rokoko i predromantizam. Naravno da duhovnopovijesne kategorije nisu kompatibilne sa svim umjetničkim/ književnim stilovima, temama i idejama, tj. da postoji stanovita sukladnost stila i ideologije. Tako su primjerice, barokni figuralni stil i tematizacija mističnih vizija (Kanižlićeva Sveta Rožalija) primjereniji katoličkoj obnovi nego prosvjetiteljstvu, kojemu su pak prikladniji racionalna obrada tematike aktualnog svijeta ili alegorije $s$ racionalnim, lako čitljivim smislom (basna). ${ }^{30}$ Razloge zbog kojih domaća književna historiografija nije pribjegavala tako

Valja svakako imati na umu da se Šicel jedini poslije Vodnika od ovdje analiziranih književnih povjesničara bavio propitivanjem metodologije književne povijesti. V. Miroslav ŠICEL, „Dosadašnje koncepcije povijesti hrvatske književnosti“", u: ISTI, Stvaraoci i razdoblja u novijoj hrvatskoj književnosti: analize i sinteze, Zagreb: Matica hrvatska, 1971.

28 ISTI, Povijest hrvatske književnosti XIX. stoljeća. Knjiga I., Od Andrije Kačića Miošića do Augusta Šenoe (1750-1881). Zagreb: Naklada Ljevak, 2004, 18. Slično određenje prosvjetiteljstva još je ranije ponudio R. BOGIŠIĆ. V. Posvete i predgovori u hrvatskih pisaca 18. stoljeća“. Hrvatska književnost 18. st., tematski i žanrovski aspekti, Dani hvarskog kazališta knj. 21. Split: Književni krug, 5-29.

29 U kratkom tekstu o 18. stoljeću u svom starijem popularno pisanom pregledu ukupne hrvatske književnosti Šicel rabi pojmove prosvjetiteljstvo i racionalizam kao sinonime (SICEL 1982:41-45). Takva se sinonimija u ovoj knjizi pojavljuje samo na jednom mjestu (str. 18).

30 U srpskoj se literaturi, odnosno u razumijevanju vlastite nacionalne književne povijesti, prosvjetiteljstvo kao viši duhovnopovijesni pojam nadređuje stilskoperiodizacjskim terminima: klasicizam i predromantizam razumiju se kao književni stilovi prosvjetiteljstva. V. Milorad PAVIĆ, Istorija srpske književnosti klasicizma i predromantizma. Beograd: Nolit, 1979, 14. S druge strane, JELČIĆ kao da se čudi istodobnosti baroka i racionalizma u slavonskoj 
usustavljenim generalizacijama valjalo bi tražiti u opsjednutosti vlastitom okcidentalnosti i svojevrsnim fetišizmom etabliranih književnopovijesnih etiketa, u koje je ulazilo i prosvjetiteljstvo, a još više iluminizam. Takva su polazišta nužno vodila ili maksimalističkom određenju prosvjetiteljstva, ili bolnom komparatističkom seciranju zaostajanja vlastite kulture.

Nominalistički pristup periodizacijskom pojmovlju, ali i „zdrav povijesni razum“, kao i dominantna predodžba o ranonovovjekovnoj kulturi, povjesničaru (književnosti) ipak nameću pretpostavku o polaganom prijelazu iz jedne u drugu paradigmu. ${ }^{31}$ Stoga, i kad se prihvati uvriježena i dobro argumentirana postavka o dvije poetički različite polovice 18 . stoljeća, ostaje problem prijelaznih oblika, začetaka novih tendencija prije njihova punog, eksplicitnog očitovanja, primjerice u Relkovićevu Satiru. ${ }^{32} \mathrm{U}$ tom smislu komponenta didaktičnosti (kao i pučko usmjerenje) teško može biti differentia specifica svjetovne, prosvjetiteljske književnosti, kako su između ostalih isticali Bogišić, Kolumbić, Šicel - nema nikakvog razloga za njezin izostanak u književnosti katoličke obnove. Upravo takve interferencije didaktičnost u religioznoj tematici i religioznost i kršćanska ideologija u tekstovima nedvojbenih prosvjetiteljskih tendencija - traže nijansirani pristup i razrađeniju terminologiju. ${ }^{33}$

Naposljetku, možemo zaključiti da su djela s prosvjetiteljskim tendencijama pisana hrvatskim jezikom na mikrorazini zadovoljavajuće opisana u domaćoj književnoj historiografiji, ali da na višoj razini njihova stilskog i idejnog atribuiranja/klasificiranja ima prostora za bolji (pre)opis.

\section{$\cos$}

\section{Enlightenment in the Croatian Literary Historiography - The Content and SCOPE of The Concept}

The authors analyse the concept of Enlightenment in the long series of synthetic, narrative surveys of Croatian $18^{\text {th }}$ century literature (Vodnik 1913, Ježić 1944, Matić 1945, Kombol 1945, Georgijević 1969, Bogišić 1974, Frangeš 1987, Novak 1999, Jelčić 2004, Šicel 2004). Apart from some

književnosti 18. st. V. Povijest hrvatske književnosti (drugo, prošireno izdanje). Zagreb: Naklada P.I.P. Pavičić, 2004 (1. izd. 1997)

31 Joanna RAPACKA vidi 18. st. kao prijelazno razdoblje u povijesti hrvatske kulture („Popularne kodifikacije domaće tradicije (iz problema oblikovanja vizije nacionalnog prostora)“. Hrvatska književnost 18. st., tematski $i$ žanrovski aspekti, Dani hvarskog kazalista knj. 21. Split: Književni krug, 121-127.)

32 Unatoč bitno različitim ortografsko-jezičnim i poetičkim orijentacijama hrvatske i srpske književnosti do sredine 18. stoljeća, iznenađuju tipološke sličnosti, odnosno slična viđenja razvoja dviju književnosti u 18. stoljeću. Naime, i u srpskoj se književnoj historiografiji ističe dvodijelnost 18. stoljeća, obično s granicom u 1770-im godinama (Jovan DERETIĆ, Istorija srpske književnosti (treće prošireno izdanje). Beograd: Prosveta. (1. izd. 1983, 2. izd. 1996, 474.).

33 Čini se da je problem kontinuiteta s prethodnom epohom u srpskoj književnoj historiografiji bolje istražen. Mislimo, naravno, na koncepte baroknog eruditizmalenciklopedizma i skolastičkog racionalizma u predprosvjetiteljskoj epohi (Milorad PAVIĆ, Istorija srpske književnosti baroknog doba, (XVII i XVIII vek). Beograd: Nolit, 1970), koje bi trebalo kritički preispitati iz suvremene teorijsko-književnopovijesne perspektive. I u hrvatskoj književnoj historiografiji ima sličnih impulsa. Dunja FALIŠEVAC piše o pomirenju prosvjetiteljskog i teološkog (religioznog) ne samo kod Relkovića nego i u onodobnoj njemačkoj književnosti (FALIŚEVAC 2000:127). Za postupne promjene u religioznoj književnosti posebno su vrijedni radovi Franje Emanuela HOŠKA i njegova primjena koncepta obnovnog/reformnog katoličanstva („Josip Pavišević u procijepu tradicije i novovjekoga cezaropapizma“, Zbornik o Josipu Paviševiću, Radovi sa Znanstvenoga skupa održanog u Osijeku 2003. godine, Osijek 2006, 17-36. v. i Ružica PŠIHISTAL Problem slavonskog baroka u hrvatskoj znanosti o književnosti“. U: Ključevi raja: hrvatski književni barok i slavonska književnost 18. stoljeća, prir. J. Matanović. Zagreb: Meandar, 70. 
differences regarding regional preferences and descriptions of individual literary works, there are some consensually accepted features of the Croatian literature of the time that have been detected already in Vodnik's History, such as: the difference in poetics between the first and the second half of the $18^{\text {th }}$ century (whereby the Enlightenment exists only in the second half), lack of the radical (deistic and atheistic) tendencies, proto-nationalism (the beginnings of the language standardization, expansion of the Croatian national designation). The Croatian literary historiography uses the concept of the Enlightenment rather as a label for a historical poetic style, just like Baroque, Rococo or Classicism, but as a category of the history of ideas. The main unsolved issue is the detailed description of the "transitional forms", such as religious literature with didactic tendencies or secular literature with some Christian values, which form a bridge between the Catholic Revival and Enlightenment.

Keywords: Enlightenment, Popular Enlightenment, Josephinism, Illuminism, Rationalism, Catholic Revival, Modernization, Croatian Literary Historiography.

\section{$\cos$}

\section{Literatura}

ANDRIĆ, Nikola (1902). Iz ratničke književnosti hrvatske (literarna slika XVIII. vijeka). Zagreb: A. Scholz. [pretisak Vinkovci: Privlačica, 1994]

BIĆANIĆ, Rudolf (1952). Počeci kapitalizma u hrvatskoj ekonomici i politici. Zagreb: Školska knjiga 1952.

BOGIŠIĆ, Rafo (1974). „Književnost prosvjetiteljstva“. U M. Franičević, F. Švelec, R. Bogišić Povijest hrvatske književnosti: Od renesanse do prosvjetiteljstva, knj. 3, Zagreb: Liber, Mladost, str. 293-383.

BOGIŠIĆ, Rafo (1975). „Hrvatska književnost 18. stoljeća“. U: Zbornik Zagrebačke slavističke škole. III (1975): Zagreb, knjiga 3, str. 9-22.

BOGIŠIĆ, Rafo (1995). „Posvete i predgovori u hrvatskih pisaca 18. stoljeća“. Hrvatska književnost 18. st., tematski i žanrovski aspekti, Dani hvarskog kazališta knj. 21. Split: Književni krug, 5-29.

DEANOVIĆ, Mirko (1933-1935). „Odrazi talijanske akademije degli Arcadi preko Jadrana“. Rad JAZU knj. 248 (1933), str 1-98; knj. 250 (1935), str. 1-125.

DERETIĆ, Jovan (2002). Istorija srpske književnosti (treće prošireno izdanje). Beograd: Prosveta. (1. izd. 1983, 2. izd. 1996.)

DUKAT, Vladoje (1944). Sladki naš kaj: ogledi iz stare kajkavske književnosti. Zagreb: Hrvatski izdavalački bibliografski zavod.

DUKIĆ, Davor (2002). Poetike hrvatske epike 18. stoljeća. Split: Književni krug.

FRANGEŠ, Ivo (1987). Povijest hrvatske književnosti. Zagreb Ljubljana: Nakladni zavod MH, Cankarjeva založba.

GEORGIJEVIĆ, Krešimir (1969). Hrvatska književnost od 16. do 18. stoljeća u sjevernoj Hrvatskoj i Bosni. Zagreb: Matica hrvatska.

HOŠKO, Franjo Emanuel (2006). „Josip Pavišević u procijepu tradicije i novovjekoga cezaropapizma“. U: Zbornik o Josipu Paviševiću, Radovi sa Znanstvenoga skupa održanog u Osijeku 2003. godine, Osijek 2006, 17-36.

JELČIĆ, Dubravko (1995). „Barokni iluminizam ili iluministički barok Adama Filipovića“. U: Ključevi raja: hrvatski književni barok i slavonska književnost 18. stoljeća, prir. J. Matanović. Zagreb: Meandar, 199-206. 
JELČIĆ, Dubravko (2004). Povijest hrvatske književnosti (drugo, prošireno izdanje). Zagreb: Naklada P.I.P. Pavičić. (1. izd. 1997)

KOMBOL, Mihovil. ('1961). Povijest hrvatske književnosti do preporoda, Zagreb: Matica hrvatska. (1. izd. 1945)

MATASOVIĆ, Josip (1921). Iz galantnog stoljeća: kulturnohistorijski fragmenti. Zagreb. [2. prošireno izd. Zagreb: Dora Krupićeva, 2008.]

MATIĆ, Tomo (1945). Prosvjetni i književni rad u Slavoniji prije Preporoda, Zagreb: HAZU. [pretisak Vinkovci: Privlačica, 1994]

NOVAK, Slobodan Prosperov (1999). Povijest hrvatske književnosti, knj. 3. Od Gundulićeva „poroda od tmine" do Kačićeva "Razgovora ugodnog naroda slovinskoga" iz 1756. Zagreb: antibarbarus.

PAVIĆ, Milorad (1970). Istorija srpske književnosti baroknog doba, (XVII i XVIII vek). Beograd: Nolit.

PAVIĆ, Milorad (1979). Historija srpske književnosti klasicizma i predromantizma. Beograd: Nolit.

PAVLIČIĆ, Pavao (1991). „Kamo pripada Reljkovićev Satir?“. U: Vrijeme i djelo Antuna Reljkovića: znanstveni skup Nova Gradiška, 25.-27. listopada 1984., ur. D. Tadijanović i J. Vončina. Osijek: JAZU, 85-94.

PERKINS, David (1992). Is Literary History Possible? Baltimore, London: The Johns Hopkins University Press.

POSAVEC, Zlatko (1991). „Reljković i estetika“. U: Vrijeme i djelo Antuna Reljkovića: znanstveni skup Nova Gradiška, 25.-27. listopada 1984., ur. D. Tadijanović i J. Vončina. Osijek: JAZU, 105-115.

PŠIHISTAL, Ružica (1995). „Problem slavonskog baroka u hrvatskoj znanosti o književnosti“. U: Ključevi raja: hrvatski književni barok i slavonska književnost 18. stoljeća, prir. J. Matanović. Zagreb: Meandar, 49-72

PŠIHISTAL, Ružica (2011). Satir nije divji čovik: studije, članci i eseji o slavonskoj književnosti. Osijek: Ogranak Matice hrvatske u Osijeku.

RAPACKA, Joanna (1995). „Popularne kodifikacije domaće tradicije (iz problema oblikovanja vizije nacionalnog prostora)“. Hrvatska književnost 18. st., tematski i žanrovski aspekti, Dani hvarskog kazališta knj. 21. Split: Književni krug, 121-127.

ŠICEL, Miroslav (1982). Hrvatska književnost. Zagreb: Školska knjiga.

ŠICEL, Miroslav (2004). Povijest hrvatske književnosti XIX. stoljeća. Knjiga I., Od Andrije Kačića Miošića do Augusta Šenoe (1750-1881). Zagreb: Naklada Ljevak.

ŠUNDALIĆ, Zlata (2005). Kroz slavonske libarice: rasprave o nabožnoj književnosti u Slavoniji. Osijek: Ogranak Matice hrvatske u Osijeku.

TATARIN, Milovan (1997). Od svita odmetnici: rasprave o nabožnim temama u Slavoniji u 18. stoljeću. Split: Književni krug.

TATARIN, Milovan (1999). Zaboravljena Oliva: rasprave o hrvatskoj nabožnoj književnosti 18. stoljeća. Zagreb: Matica hrvatska.

TATARIN, Milovan (2007). Ljubavi nebeske, ljubavi zemaljske: prilozi hrvatskoj nabožnoj književnosti 18. stoljeća. Zagreb: Disput.

VODNIK [=Drechsler], Branko (1907). Slavonska književnost u XVIII. vijeku. Zagreb: M. Breyer. [pretisak Vinkovci: Privlačica, 1994]

VODNIK, Branko (1913). Povijest hrvatske književnosti. Knjiga I. Od humanizma do potkraj 18. st. Zagreb: Matica hrvatska. 